\title{
Illustrations and Maps
}

following page 122

Ani Yeshe

Karsha nunnery

Karsha monastery

The assembly of Karsha nuns

Bowing and scraping

Ritual assembly

Tantric visualizations

Offering cakes

Barley and butter

Demons and dogs

Nunnery school

Apprenticeship

Palkyid with child

Shaving heads

Watering the barley fields

Bringing dung

Bringing thistle

Brushing pile

Construction at the nunnery

Window of a nun's cell

Maps

1. Jammu and Kashmir State

2. Zangskar 40

3. Karsha nunnery $80-81$ 
